\title{
BAKER'S THEORY OF MATERIAL CONSTITUTION AND THINKING THINGS INTO EXISTENCE
}

\begin{abstract}
The paper provides a critical evaluation of Lynne Rudder Baker's nonmereological theory of material constitution in light of the "thinking into existence" objection, formulated by Theodore Sider and Dean W. Zimmerman. Although Baker responds to it, she focuses on its specific versions presented by Sider and Zimmerman and does not address the source of the problem. Baker maintains that beliefs, social practices, and conventions can bring a new intention-dependent object into existence. However, as I argue, the thinking into existence objection shows that constituted objects, if there are any, are ontologically independent of beliefs, social practices, and conventions. In fact, Baker's theory doesn't give us any reason for believing that intentiondependent objects are any more real than fictional objects.
\end{abstract}

Keywords: material constitution, ontology, fictional objects, thinking into existence

In this paper, I critically evaluate Lynne Rudder Baker's nonmereological theory of material constitution in light of the "thinking into existence" objection, raised most powerfully by Theodore Sider (2001) and Dean W. Zimmerman (2002). Baker's response to the objection focuses on its specific versions formulated by Sider and Zimmerman and does not address the source of the problem. In section 1, I give a brief summary of Baker's theory of material constitution and then, in section 2, discuss both the thinking into existence objection and Baker's response to it. In section 3, I apply the thinking into existence objection to fictional objects and argue that the objection raises a much more serious problem for Baker's theory than she addresses in her response. I close with a brief recapitulation of the conclusion (section 4).

* Department of Philosophy, Bilkent University, H249 Bilkent, Ankara 0680o, Turkey, tufan.kiymaz@bilkent.edu.tr. 


\section{BAKER'S THEORY OF MATERIAL CONSTITUTION}

In what follows, I focus on three books in which Baker develops and defends her views on constitution: Persons and Bodies (2000), The Metaphysics of Everyday Life: An Essay in Practical Realism (2007), and Naturalism and the First-Person Perspective (2013). There, Baker develops a purportedly common-sense approach to metaphysics called practical realism. It asserts that ordinary objects, such as trees, chairs, and statues, exist and are neither eliminable nor reducible to more basic entities; they are as real as the fundamental particles by which they are ultimately constituted.

The fundamental idea of constitution, according to Baker, is this: When things of a certain primary kind are in certain circumstances, a thing of a different primary kind - a new object, with different persistence conditions and different causal powers - comes into existence (2013: 224; 2007: 32; 2002: 32). The primary kind of $x$ is what, most fundamentally, $x$ is (Baker 2007: 33; 2013: 147). Things have their primary-kind properties essentially: i.e., if $x$ is primarily an $\mathrm{F}$, then $x$ cannot exist without being an $\mathrm{F}$.

When, for example, a piece of marble is in certain conditions, "statuefavorable conditions" in Baker's terminology, such as bearing a certain relation to the art world, a statue comes to exist. A statue and a piece of marble are of different primary kinds: namely, statue and piece of marble.

According to Baker, when $x$ constitutes $y$, the coming-into-existence of $y$ brings into being new causal powers (Baker 2002: 33, also see Baker 2000: 41; 2007: 32). But when do new causal powers indicate that a new thing has come into existence and not that an already existing thing has acquired a new property? Baker writes:

A theory of primary kinds would provide a principled way to distinguish between cases $\ldots$ in which an object merely acquires a property and cases . . . in which a new entity comes into existence. Since a theory of primary kinds would be tantamount to a theory of everything, it is not surprising (although still regrettable) that I do not have one. (2000: 40-41)

In her later works, she does not offer a theory of primary kinds either. However, in Persons and Bodies (2000), she suggests an alternative consideration that could help us in the absence of such a theory; she utilizes this principle in her later works to distinguish between constitution and mere property acquisition:

If $x$ constitutes $y$, then $y$ has whole classes of causal properties that $x$ would not have had if $x$ had not constituted anything. (Baker 2000: 41) 
So, new causal powers that belong to the constituted object cannot be reduced to the causal powers of the constituting object. But this is not really helpful either. How do we know whether the causal powers of $x$ that are irreducible to $x$ 's other causal powers belong to $x$ itself or to a new object that spatially coincides with $x$ ?

Baker gives an example to clarify. If we use an anvil to hold open a barn door, the anvil does not thereby constitute a new object - a doorstop. This is because

The anvil acquires the property of being a doorstop by our enlisting a physical property of the anvil - its heaviness - for a special purpose: to hold open the barn door. The use of the anvil as a doorstop does not bring about instantiation of whole classes of properties that anvils per se do not have. (2000: 41)

However, she also asserts that when a nonhuman primate uses a thin stick to get out edible insects from holes "the natural stick comes to constitute an implement, an artifact, by the intentional use made of it" (2013: 199). What is the relevant difference between using an anvil as a doorstop and using a stick to reach inside holes for insects? Why can we not say that the primate is simply enlisting a physical property of the stick - its shape - for a special purpose rather than bringing a new thing into existence?

Baker insists that we know some clear cases of constitution but if it is not obvious whether a particular case is an instance of constitution or property acquisition, we should establish whether the object in question has genuinely new causal powers. Importantly, an object can have some of its causal powers in virtue of being associated with social practices and intentional attitudes about it. There are some objects, such as "carburetors, cathedrals, menus, birth certificates, flags, search warrants, trophies, obituaries," that cannot exist without beliefs, desires, and intentions about them (Baker 2000: 35). Such an object is what Baker calls an "intention-dependent object" or an "IDobject" (Baker 2007: 11). All artifacts, which have their intended functions as essential properties, are ID-objects (Baker 2013: 198).

Lastly, on Baker's theory, things have their properties in two ways. If $x$ has property $\mathrm{H}$, then either $x$ has $\mathrm{H}$ nonderivatively or $x$ has $\mathrm{H}$ derivatively. $x$ has $\mathrm{H}$ derivatively iff $x$ borrows $\mathrm{H}$ from another object to which $x$ has constitution relations, otherwise $x$ has H nonderivatively. For example, David, the statue, is derivatively 6 tons because David borrows its weight from a piece of marble in virtue of being constituted by it. If $x$ has property $\mathrm{H}$ derivatively, it still really has H. David is really 6 tons, albeit derivatively so. Likewise, the piece of marble is derivatively a statue. 


\section{THE THINKING INTO EXISTENCE OBJECTION}

Sider's objection to Baker's theory of constitution is that "it is tempting to conclude that she thinks we create the world, that these continuants exist because we have concepts for them" (Sider 2001: 3-4). Zimmerman points out a similar unpalatable implication of Baker's theory: "Changes in our ways of talking about things, even coupled with simple changes in some of our nonverbal reactions to things, could by themselves bring any concrete [intention-dependent] physical object into existence" (Zimmerman 2002: 335).

Baker's reply to the claim that according to her theory we create the world by our concepts is "yes and no" (2002: 48; 2007: 46). Yes, Baker says, some objects, namely ID-objects, match our concepts because we manufacture them to match our concepts. But, when it comes to non-ID-objects, no, we do not create them, they could still exist even if we had no intentions and propositional attitudes about them.

Contrary to how Sider and Zimmerman interpret Baker's theory, she explicitly rejects that thought and talk alone, or primarily, can bring things, including ID-objects, into existence. She points out that not only having concepts of things and some nonverbal reactions to them, but also having conventions and social practices about these things is required for creating IDobjects. And these practices that are capable of creating new things cannot be whimsical: "I do not think that we just conjure up new concrete physical objects of an afternoon," Baker says (2007: 46). Intricate long-term economic practices and conventions are required for, say, a piece of paper to constitute a dollar bill.

Given that our practices and conventions can make dollar bill a primary kind, Zimmerman asks if the same can be done with president? Can we make president a primary kind? "How differently would we have to talk and act before G. W. Bush, the man, would come to coincide with another thing, a person (derivatively) who is (nonderivatively) commander-in-chief of the armed forces, etc. but who will outlive the man G. W. and always be president?" (Zimmerman 2002: 334).

Baker gives two replies to this question. First, she points out that we do not currently believe that we have a president who has been constituted by different persons in the past and she states that bringing ID-objects into existence is not done by treating an already existing kind as a primary kind:

We did not start with passports as nonprimary kind and then use our talk and thought to convert them into primary kinds. The sort of talk and thought that can contribute to bringing a new primary kind into existence is not talk and thought about a kind that existed already as an old nonprimary kind (like president). (Baker 2007: 45) 
Secondly, she argues that the notion of conventions and practices that can make president a primary kind is unrealistic; our conventions are based on our interests and we cannot choose and change our interests at will (2007: 45).

\section{THINKING ABOUT FICTIONAL OBJECTS}

I do not think Baker's replies are convincing. The idea that long-term conventions and practices can create new things is in some respects as problematic as the idea that thought and talk alone can create new things.

Suppose, in a society of idol worshipers, a craftsman carves an idol out of wood. It is not just a piece of wood anymore; it is an idol constituted by a piece of wood. An adherent of Baker's theory of constitution should concede that religious practices and conventions can create idols in the same way economic and artistic practices and conventions create dollar bills and statues.

However, probably, or at least possibly, the first idol in human history was not manufactured but found in nature. Take the sun, for example. It existed for a long time before people worshiped it as a god. Sun worshipers did not manufacture the sun, but they utilized it in their religious practices. They, as a society, worshiped, prayed, feared, and loved the sun as their god. The sun does seem to have constituted a new ID-object: the sun-god. Baker's theory of material constitution implies that, in certain circumstances, the sun constitutes a god, which is a real addition to the ontology of the world. ${ }^{1}$

As I already mentioned, Baker takes her theory of constitution to be grounded in common sense. But it seems that a proponent of this theory should concede that, for example, a sun-god comes into existence in virtue of the religious beliefs and practices of a sun-worshiping society or the universe constitutes and really becomes (derivatively) a god in virtue of the religious beliefs and practices of a pantheistic society. Contrary to what Baker says about her account, I don't think these claims are commonsensical. This is a problem, but these considerations reveal an even more serious difficulty, as we shall see next.

According to Baker, conventions and practices cannot create an ID-object ex nihilo, but only make an already existing object constitute a new ID-object. Baker states that "conventions, practices, and preexisting materials" are re-

${ }^{1}$ To be consistent with Baker's views on personhood, this has to be a non-personal god. According to Baker's (2013) constitution view of persons, having a first-person perspective is a necessary condition for personhood, which cannot be conferred upon a body by social practices and conventions. 
quired for constitution of ID-objects (2007: 46, emphasis added). So, worshiping practices can bring into existence an idol or god, which is constituted by, say, a piece of wood or the sun, but if the same worshiping practices are directed at a fictional object, such as a deity that resides on Mount Olympus, they cannot bring that being, Zeus, into existence. But why not? It seems that a nonexistent Zeus had very similar causal powers to whatever causal powers an idol nonderivatively (that is, in virtue of being an idol) has, which are based on religious beliefs and practices. ${ }^{2}$

The important point is this: We know that the worshiping practices and religious conventions associated with Zeus do not confer causal powers upon Zeus, since Zeus does not exist. What is it, then, that makes it the case that very similar practices and conventions associated with an existing piece of wood confer a new set of causal powers upon it and thereby constitute an idol? If practices and conventions are not sufficient for Zeus to come into existence, then I cannot see how very similar practices and conventions are sufficient for any constituted object to come into existence when they are directed at some existent material.

To elaborate: According to the picture Baker paints, a piece of wood constitutes an idol in virtue of the religious beliefs, practices, and conventions of a society and the idol is a new thing because it has a new set of causal powers that the piece of wood qua a piece of wood lacks. What are those causal powers that the idol has? Presumably, the powers to lead and motivate members of the society to do certain things, such as pray, fear, perform certain rituals, punish individuals who disrespect the piece of wood, etc. ${ }^{3}$ My point is that both the idol, qua idol, and Zeus seem to have the same causal powers and yet Zeus cannot have any causal powers because he does not exist. So, if Zeus does not play a causal role in the religious attitudes and behaviors of a Zeusworshiping society, then arguably neither does the idol (as an alleged further entity constituted by a piece of wood) in an idol-worshiping society. The idol does not have a new set of causal powers that the piece of wood lacks.

In short, in light of Baker's emphasis on social practices and conventions and given that we have social practices and conventions about nonexistent things, if ID-objects, such as idols, statues, cars, dollar bills, etc., are not

${ }^{2}$ If, per impossibile, Zeus were constituted ex nihilo, he wouldn't be a personal god, but still, according to what Baker says about generation of new causal powers by social practices and conventions, he would genuinely be part of the ontology of the world. See footnote 1.

3 According to Baker (1999: 147; 2000: 33) the new causal powers of a monument are that it "attracts speakers and small crowds on patriotic holidays; it brings tears to people's eyes; it arouses protests." I think it is safe to say that an idol would have had similar causal powers to those of a monument. 
identical to (a temporal part of) their material, then I cannot see why we should think that they are more real than Zeus. In short, in light of Baker's emphasis on the essential role of social practices and conventions in the existence of ID-objects such as idols, statues, cars, dollar bills, etc., and given that we have very similar social practices and conventions about nonexistent things, I cannot see why we should think that ID-objects are more real than fictional entities like Zeus.

\section{CONCLUSION}

In this paper, I have applied Sider and Zimmerman's thinking into existence objection to fictional objects that are treated by the society as real. Baker's nonmereological theory of material constitution cannot account for the ontological difference between a constituted real ID-object and a fictional object associated with social practices and conventions similar to those that are directed at real materials. It is unacceptable that real objects, such as a real mythological creature, can be created ex nihilo in virtue of beliefs and social practices directed at that creature. People's sincere belief in the existence of a fictional object and the fact that the object is treated as real in their long established social practices and conventions does not bring that object into existence. But if social practices cannot bring a fictional object into existence, then it is hard to see how the same sort of social practices can make an ID-object emerge from an existing material. Therefore, pace Baker, it seems that beliefs, social practices, and conventions cannot endow any (real or fictional) object with real causal powers and thereby cannot bring a new object into existence.

\section{BIBLIOGRAPHY}

Baker L. R. (1999), “Unity without Identity: A New Look at Material Constitution,” Midwest Studies in Philosophy 23(1), 144-165.

Baker L. R. (2000), Persons and Bodies: A Constitution View, Cambridge Studies in Philosophy, Cambridge-New York: Cambridge University Press.

Baker L. R. (2002), “On Making Things Up: Constitution and Its Critics," Philosophical Topics 30(1), 31-52.

Baker L. R. (2007), The Metaphysics of Everyday Life: An Essay in Practical Realism, Cambridge Studies in Philosophy, Cambridge-New York: Cambridge University Press. 
Baker L. R. (2013), Naturalism and the First-Person Perspective, Oxford-New York: Oxford University Press.

Sider T. (2001), "Review of Lynne Rudder Baker, Persons and Bodies," The Journal of Philosophy 99, 45-48.

Zimmerman D. W. (2002), "The Constitution of Persons by Bodies: A Critique of Lynne Rudder Baker's Theory of Material Constitution,” Philosophical Topics 30(1), 295-338. 